\title{
Corrigendum: Demands-abilities fit, work beliefs, meaningful work and engagement in nature-based jobs
}

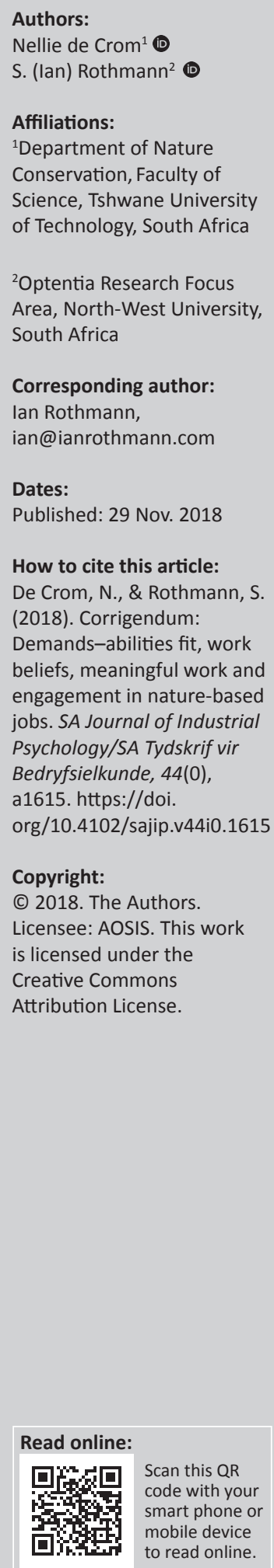

Published: 29 Nov. 2018

How to cite this article: De Crom, N., \& Rothmann, S. (2018). Corrigendum: Demands-abilities fit, work beliefs, meaningful work and engagement in nature-based jobs. SA Journal of Industrial Psychology/SA Tydskrif vir Bedryfsielkunde, 44(0), a1615. https://doi. org/10.4102/sajip.v44i0.1615

\section{Copyright:}

(C) 2018. The Authors.

Licensee: AOSIS. This work

is licensed under the

Creative Commons

Attribution License.

In the author list of this article initially published, Nellie de Crom's affiliation was incorrectly listed as the 'Faculty of Agricultural Sciences, Tshwane University of Technology, South Africa'. The correct affiliation is as follows: 'Department of Nature Conservation, Faculty of Science, Tshwane University of Technology, South Africa'. The author sincerely apologises for any inconvenience caused. 